\title{
Pemberian Penghargaan Dalam Pameran Besar Seni Lukis Indonesia dan Biennale Jakarta 1974-1989
}

\author{
Genardi Atmadiredja ${ }^{1}$, Ira Adriati ${ }^{2}$ \\ ${ }^{1}$ Pusat Penelitian Kebijakan Pendidikan dan Kebudayaan, Balitbang Kementerian Pendidikan dan \\ Kebudayaan, Jalan Jenderal Sudirman-Senayan, Jakarta, 10270, Indonesia
}

${ }^{2}$ Prodi Seni Rupa, Fakultas Seni Rupa dan Desain ITB, Jalan Ganesha 10, Bandung, 40132, Indonesia

Iominoreg87@gmail.com

Dalam sejarah perkembangan seni rupa Indonesia setelah kemerdekaan, pemberian penghargaan yang bersifat nasional dipelopori oleh Dewan Kesenian Jakarta melaui Pameran Besar Seni Lukis Indonesia (PBSLI) pada 1974. PBSLI memberikan penghargaan pada karya terbaik melalui mekanisme penjurian. Dinamika yang terjadi pasca pemberian penghargaan tersebut menimbulkan persepsi dan opini yang berbeda mengenai bagaimana karya seni yang baik kala itu. Kajian ini akan melihat dampak pemberian penghargaan PBSLI, kemudian berganti nama menjadi Biennale Jakarta pada 1982, dari sisi mekanisme pemilihan seniman, penjurian, situasi sosial, dan opini yang berkembang di dunia seni rupa Indonesia periode 1974-1989. Kajian ini menggunakan metode penelitian kualitatif dengan pendekatan sejarah. Pengumpulan data melalui penelusuran arsip dan wawancara. Dengan pendekatan teori Medan Artistik Bourdieu, kajian ini menemukan bahwa melalui pemberian penghargaan ini, seniman mendapatkan modal simbolik dari suatu penyelenggaraan kompetisi yang menjadi pembeda dan penentu selera zaman.

Kata kunci: Penghargaan seni, seni rupa, PBSLI, Biennale Jakarta

\section{Awarding for the Great Exhibition of Indonesian Painting and Jakarta Biennale in 1974-1989}

In the history of the development of post-independence Indonesian art, the national award was initiated by Dewan Kesenian Jakarta (The Jakarta Arts Council) through Pameran Besar Seni Lukis Indonesia (PBSLI) or The Great Exhibition of Indonesian Painting in 1974. PBSLI awarded the best work through the judging mechanism. The dynamics occurred after the award gave rise to different perceptions and opinions about how good works of art at the time were. This study examines the impact of PBSLI and Biennale Jakarta, the event's name was altered in 1982, in terms of artist selection process, judging, social situation, and opinions in the Indonesian arts during 1974-1989. This study uses the qualitative research method with a historical approach. Data were collected through archival research and in-depth interviews. By implementing Artistic Field of Bourdieu, the study demonstrates that the results of PBSLI and Biennale Jakarta bestowed artists a symbolic capital which characterized the taste of arts at that time.

Keywords: Art awards, visual arts, PBSLI, Biennale Jakarta.

Proses Review : 1 - 28 Januari 2020, Dinyatakan Lolos: 10 Februari 2020 


\section{PENDAHULUAN}

Pameran Besar Seni Lukis Indonesia (PBSLI) dan Biennale Jakarta merupakan sebuah program rutin Dewan Kesenian Jakarta (DKJ). Program ini diselenggarakan dalam rangka pembinaan dan pengembangan seni rupa Indonesia dan menjadi bagian dari program kebudayaan Taman Ismail Marzuki (TIM). PBSLI berlangsung sejak tahun 1974 hingga 1980, kemudian pada tahun 1982 berganti nama menjadi Biennale Jakarta. Dalam penyelenggaraannya, pemberian penghargaan bagi karya terbaik merupakan bagian yang memancing perdebatan. Hal ini tidak terlepas dari struktur Dewan Kesenian Jakarta yang terdiri dari budayawan dan seniman senior yang menjadi penentu karya terbaik. Kajian ini akan membahas mengenai posisi pemberian penghargaan seni rupa yang berlangsung di Indonesia.

Untuk melihat persoalan seputar pemberian penghargaan seni rupa di Indonesia, kita dapat menelusurinya ke belakang, sejak era kolonial, masa pendudukan Jepang, dan setelah kemerdekaan. Pemberian penghargaan bagi seniman Indonesia memiliki dampak yang signifikan. Dalam tulisan Imam Boechori pada 'Latar Belakang, Sedjarah Pembinaan, dan Perkembangan Seni Lukis Indonesia 1935-1959' bahwa mentalitas dari Soedjojono sebagai seniman dan penggagas PERSAGI kian kuat ketika Soedjojono mengikuti suatu sayembara lukis yang diselenggarakan oleh pemerintah kolonial kala itu dan mendapatkan apresiasi baik. Karya Soedjojono diapresiasi dengan dijadikan salah satu sampul publikasi pameran tersebut (Zainuddin, 1966). Pada zaman pendudukan Jepang, tercatat beberapa pemberian penghargaan pada seniman Indonesia melalui lembaga kebudayaan Jepang, yaitu pada 27 April 1943 dan 20 November 1943. Penerima penghargaan tersebut antara lain Emiria Sunasa, GA Soekirno, Agus Djaya, Otto Djaya, Barli, dan Soebanto Surjosubandrio (Zainuddin, 1966). Seniman pada masa itu mendapatkan penghargaan berupa peralatan kesenian dari lembaga kebudayaan Jepang (Keimin Bunka Sidhoso). Pada masa tersebut, Jepang sangat memperhatikan perkembangan seniman Indonesia sebagai bagian dari propaganda. Pemberian penghargaan dan bentuk perhatian lainnya memicu tumbuhnya seniman dan kelompok-kelompok seni. Seniman yang diberikan penghargaan tentu saja seniman yang secara kekaryaan mendukung propaganda Jepang sebagai cahaya baru Asia.

Memasuki era setelah kemerdekaan Indonesia, ajang pemberian penghargaan seni rupa Indonesia baru kembali ramai ketika DKJ menyelenggarakan PBSLI pada 1974. Pada tahun pertamanya, PBSLI mendapat protes dari sebagian seniman yang merasa kecewa dengan keputusan dewan juri. Dewan juri dirasa memiliki suatu keberpihakan yang tidak mendukung kebaruan dalam seni lukis Indonesia. Pemberian penghargaan oleh DKJ ini rutin diselenggarkan setiap 2 tahun hingga tahun 1982 yang kemudian berganti nama menjadi Biennale Jakarta. Pemberian penghargaan DKJ berhenti pada 1989 hingga sekarang. Era selanjutnya adalah penyelenggaraan Philip Morris Indonesia Art Award (PMIAA) yang merupakan sebuah kompetisi seni rupa berskala nasional hingga regional Asia. Dalam tesis Yuliana Kusumastuti yang berjudul 'Market Forces: A Case Study of Contemporary Art Practice in Indonesia' dibahas secara khusus mengenai dampak pemberian penghargaan. Kusumastuti membahas PMIAA yang mulai diselenggarakan pada 1994. PMIAA muncul dengan hadiah yang besar, sehingga daya tariknya bagi seniman menjadi ajang unjuk kemampuan sekaligus menaikkan harga karya-karya mereka. Agus Dermawan (dalam Kusumastuti, 2006;53) mengatakan bahwa PMIAA pada kali pertama hingga tahun ketiga merupakan suatu hal yang memuaskan, karena pemenang pada PMIAA juga mampu untuk mendapatkan penghargaan di ajang ASEAN Art Award (Kusumastuti, 2006).

Dari beberapa penyelenggaraan pemberian penghargaan seni rupa Indonesia, selera juri sangat berperan dalam menentukan seniman atau karya yang menerima penghargaan. Kajian ini akan melihat bagaimana selera dari dewan juri yang terlihat dari pemilihan seniman atau karya yang menjadi juara dan bagaimana respon dari medan seni terhadap pilihan juri tersebut. Kajian ini akan mengambil sampel kasus pemberian penghargaan yang diselenggarakan oleh DKJ sejak tahun 1974 hingga 1989. Kajian ini dapat menjadi suatu pertimbangan bagi seniman ataupun pengamat seni dalam melihat dampak dari suatu penyelenggaraan penghargaan seni rupa Indonesia. Selain itu kajian ini mencoba menuliskan pembabakan perkembangan seni rupa Indonesia melalui sejarah pemberian penghargaan seni rupa.

\section{METODE PENELITIAN}

Kajian ini akan melihat dinamika yang terjadi dalam pemberian penghargaan bagi seniman/ karya terbaik dalam PBSLI dan Biennale Jakarta meliputi mekanisme yang diterapkan dalam penyelenggaraan, penentuan dewan juri, respon publik, dan respon media. Pengumpulan data pada kajian ini meliputi studi pustaka, penelusuran arsip media massa, dan wawancara.

Kompetisi dan penghargaan seni rupa yang berlangsung di Indonesia merupakan tempat bertemunya para agen. Agen-agen yang terlibat dalam kompetisi memiliki modal yang berlainan dan ditempatkan dalam posisi-posisi yang sesuai dengan modalnya. Misalnya seorang juri, adalah agen yang memiliki modal kultural dan modal simbolik yang baik. Biasanya juga akan dipilih oleh penyelenggara dari kalangan akademisi atau seniman yang sudah dianggap maestro. Dewan Juri memiliki peran yang sangat signifikan, di mana menjadi ujung tombak dalam memberikan penilaian bagi karya terbaik. Dengan kewenangan semacam itu, dewan juri harus memiliki modal kultural 


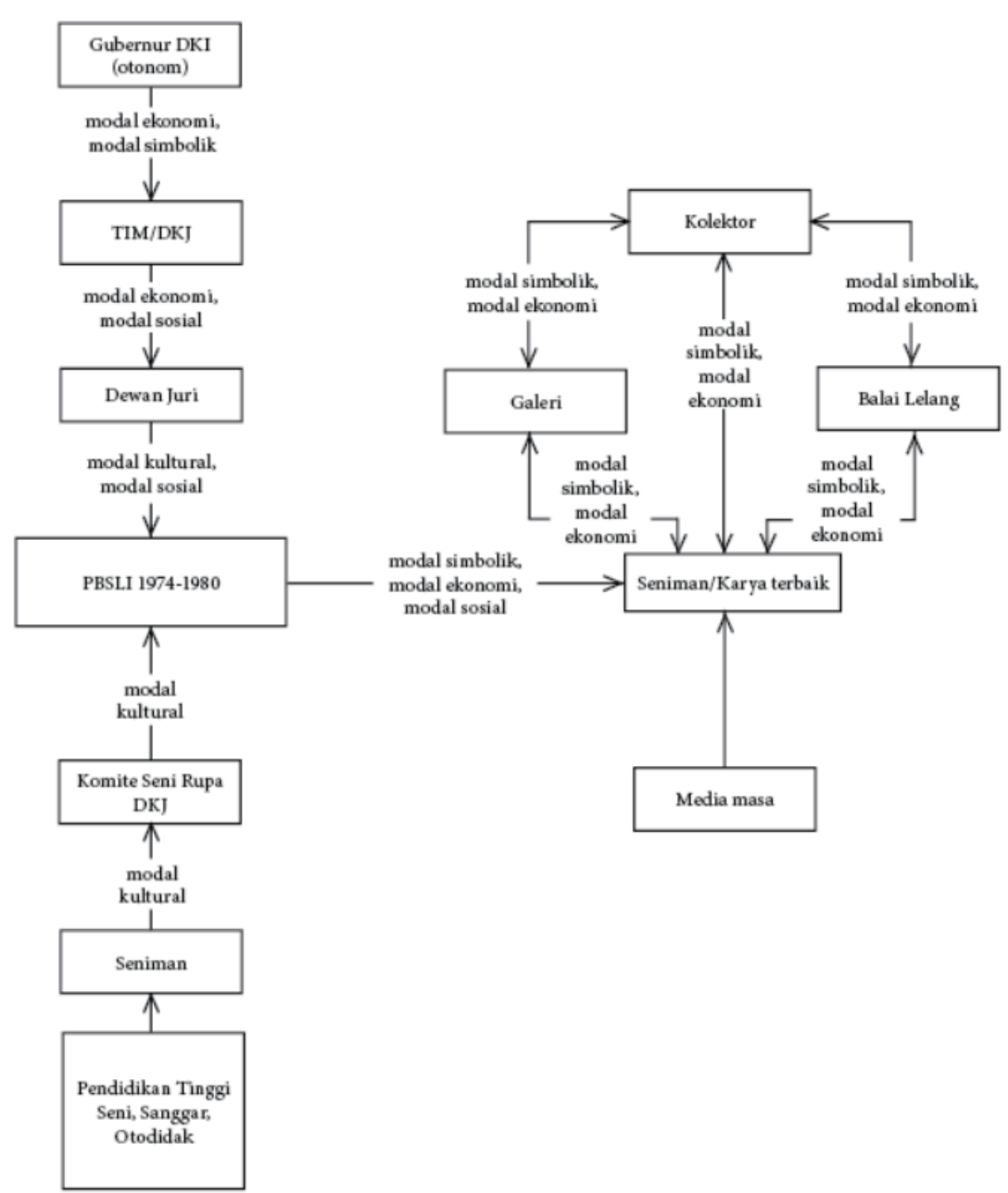

Gambar 1. Struktur relasi antar agen dalam PBSLI 1974-1980

pengetahuan seni rupa yang juga terbaik.

Dengan memiliki aturan mainnya sendiri, kompetisi merupakan medan di dalam medan seni rupa itu sendiri. Struktur relasi yang terbangun dalam kompetisi menciptakan posisi baru dari suatu agen. Misalnya saja, seorang kolektor yang memiliki modal ekonomi yang besar dapat berperan sebagai penyelenggara suatu kompetisi atau bertindak sebagai sponsor. Dalam hal ini terjadi konversi peran, dari seorang kolektor menjadi sponsor. Begitupun dalam konversi yang terjadi ketika kolektor berperan sebagai dewan juri, statusnya sebagai tokoh terpandang tidak serta merta hilang bila berperan sebagai dewan juri, justru dengan modal tertentu dapat menaikkan derajat dari penyelenggaraan kompetisi tersebut. Kompetisi mempertemukan dan menciptakan seperangkat sistem tersebut. Dalam teori Medan Artistik Bourdieu, objektivikasi suatu karya seni bukan merupakan peranan satu agen saja, namun terjadi karena keseluruhan agen yang saling berelasi, berupa suatu konsensus.

Sejarah pemberian pengharaan seni rupa yang terjadi di Indonesia menampilkan karya-karya yang merespon ge- jala zamannya. Layaknya sebuah teks yang dapat dibaca dan di interpretasikan sesuai kondisi zamannya. Sebagai sebuah teks, karya seni merupakan interaksi dan dialog dalam rentang sejarah (Iwan Saidi \& Siregar, 2016). Sehingga dalam kajian ini digunakan pendekatan kesejarahan untuk memahami peristiwa yang terjadi dalam pameran yang mengiringi pemberian penghargaan karya terbaik

\section{MELIHAT PBSLI DAN BIENNALE JAKARTA}

Untuk mempermudah melihat struktur relasi yang terjadi dalam PBSLI periode 1974-1980, dapat dilihat pada gambar 1 .

Berdasarkan gambar tersebut seniman-seniman yang berpameran dalam PBSLI diharuskan melalui tahap penyaringan dari anggota komite seni rupa atau dapat dikatakan sebagai tim riset dari DKJ untuk melihat potensi seniman Indonesia. Kemudian seniman yang dirasa memiliki potensi diberikan undangan untuk mengikuti PBSLI. Seniman yang berpameran di PBSLI kemudian dinilai oleh tim dewan juri untuk akhirnya diberikan penghargaan tertinggi dengan kriteria yang telah ditetapkan bersama. 
Pada tahapan ini, DKJ menjadi sumber inisiatifnya untuk mencari seniman-seniman yang memiliki potensi dalam perkembangan seni rupa Indonesia. Karena memang diberikan tugas oleh Gubernur DKI saat itu untuk mengembangkan kebudayaan Indonesia (Dewan Kesenian Jakarta, 1993). Program pemberian hadiah kepada karya terbaik hanya sebagai suatu pemicu untuk menciptakan iklim berkesenian yang lebih baik.

Dalam suatu kesempatan, sebagai dampak dari pemberian hadiah ini, PBSLI 1974 mendapatkan kritik dari beberapa seniman yang merasa bahwa karya yang terpilih tidak memuaskan sebagian pihak. Sebagimana yang dikenal dengan peristiwa 'Desember Hitam'. Hal ini, sebenarnya, menjadi suatu yang wajar dalam suatu sayembara. Namun yang menjadi menarik untuk diperhatikan adalah sekelompok seniman yang memprotes pilihan dewan juri, tidak terlalu berdampak pada penyelenggaraan PBSLI tahun berikutnya. Penyelenggara tetap pada koridor mereka. Dalam kerangka hubungan antaragen, kelompok pemrotes merupakan agen perubahan, atau suatu usaha suatu agen untuk merubah struktur di mana struktur tersebut tidak terlalu berpengaruh, yang pada akhirnya justru agen perubahan itu sendiri yang tertimbun dalam struktur yang telah mapan.

PBSLI dalam hal ini memiliki dominasi yang kuat, hingga mampu secara konsisten berada dalam keputusan mereka. Dominasi ini bersumber pada kedekatannya dengan penguasa, yang dalam hal ini direpresentasikan dengan Gubernur. Selain itu kebijakan kebudayaan yang diterapkan pada masa awal Orde Baru yang mengedepankan sistem komando yang masih menjaga dengan ketat terhadap kemunculan kembali ideologi-ideologi yang merongrong negara, sehingga cenderung satu arah. Sementara peristiwa tersebut pada sisi yang lain adalah protesnya mahasiswa kepada dosen mereka yang kebetulan bertindak sebagai juri. Dari sisi ini, peristiwa tersebut sudah menyentuh medan lain di luar medan seni rupa, yaitu medan perguruan tinggi, dan semakin mengkerdilkan pihak yang memprotes. Dalam wawancara, Jim Supangkat menyebutkan bahwa terdapat kemungkinan lain, bahwa PBSLI 1974 bisa jadi merupakan ajang pembuktian bahwa seniman Jogja, khususnya ASRI tidak berpaham kiri. Maka dewan juri yang berasal dari lingkungan ASRI cenderung memilih karyakarya yang non-realisme sosial.

Kebijakan kebudayaan pada masa awal Orde Baru memang tidak secara langsung beririsan dengan kebijakan yang dijalankan oleh TIM. TIM berdiri pada tahun 1969 dengan beranggotakan seniman dan budayawan yang berpandangan humanisme universal (Zurmailis, 2018). Jika merunut pada peristiwa di mana perdebatan antara pandangan komunis dengan pandangan humanisme universal, kita bisa melihat alasan pemilihan anggota TIM. Kaum humanisme universal memandang diri pribadi sebagai individu yang otonom dan terbebas dari ikatan politik, dan hanya mencari kesejatian estetik, sementara komunisme yang kuat dengan LEKRA dan PKI-nya, terlihat sangat berpihak pada ideologi komunis. Kaum humanisme universal tersebut memiliki kedekatan dengan militer pada masa itu.

Setelah peristiwa 1965 pecah, komunisme disingkirkan, tersisa humanisme universal dengan afiliasinya bersama militer. Seiring pembubaran organisasi yang berpandangan komunis, humanisme universal kian berkibar dengan bentuk-bentuk kesenian yang ditampilkannya. Kaum humanisme universal mendapatkan dan menempatkan diri pada komunitas-komunitas seni di Indonesia. Salah satunya adalah TIM. Dengan dominasi kekuasaan yang dijalankan oleh Orde Baru, hampir seluruh pergerakan kritis dibatasi demi stabilitas bangsa. Kaum humanis universal dalam seni rupa dianggap tidak berbahaya dan dapat dibiarkan berkembang.

Periode selanjutnya adalah penyelenggaraan Biennale Jakarta 1982 hingga 1989, dimana kondisi TIM saat itu sudah berada dalam struktur organisasi Pemerintah DKI, dan anggota TIM diangkat sebagai Pegawai Negeri Sipil (PNS) (Pusat Kesenian Jakarta Taman Ismail Marzuki, Yayasan Kesenian Jakarta, 2008). Untuk memudahkan perhatikan gambar 2 .

Kondisi TIM pada periode tahun 1982 hingga 1990-an tercatat beberapa perubahan yang cukup signifikan. Terutama dalam soal penganggaran, di mana TIM tidak memiliki otonomi seperti pada era Gubernur Ali Sadikin. Dampak langsung dari kesulitan pendanaan program-program TIM bisa terlihat dari penyelenggraan Biennale Jakarta yang mulai tidak rutin dan sepi pengunjung akibat promosi yang terbatas. Situasi ini pula yang mendorong manajeman TIM untuk membuka diri pada pihak swasta.

Pihak swasta yang masuk dalam pembiayaan program-program kebudayaan di TIM ikut menentukan budaya yang ditampilkan. Hal ini menyebabkan kesenian TIM semakin terisolasi dari rakyat (Hill dalam (Jones, 2015)). Pernyataan tersebut dapat diperkuat dengan berbagai media massa pada periode tersebut yang menyatakan bahwa karya-karya yang tampil di Biennale Jakarta pun jauh dari publik, dan seniman hanya bersemayam di 'menara gading' seperti yang dituliskan dalam koran 'Harian Merdeka' edisi 14 Januari 1981. Sementara kebijakan kebudayaan Orde Baru tetap dengan budaya komando yang otoritarian. Sejatinya, DKJ tidak berkenan bila pemerintah banyak mengintervensi program-program kebudayaan TIM, sehingga DKJ cenderung membuka diri terhadap investasi swasta untuk akhirnya mengimbangi hak-hak penyandang dana. Hal tersebut bukan suatu perkara yang mudah, di mana setelah Ali Sadikin lengser dari Gubernur Jakarta, pemerintah selanjutnya mengambil alih dan memasukkan pengelolaan TIM kepada struktur birokrasi Pemerintah Daerah DKI yang kala itu pendanaannya cenderung tersendat. TIM 


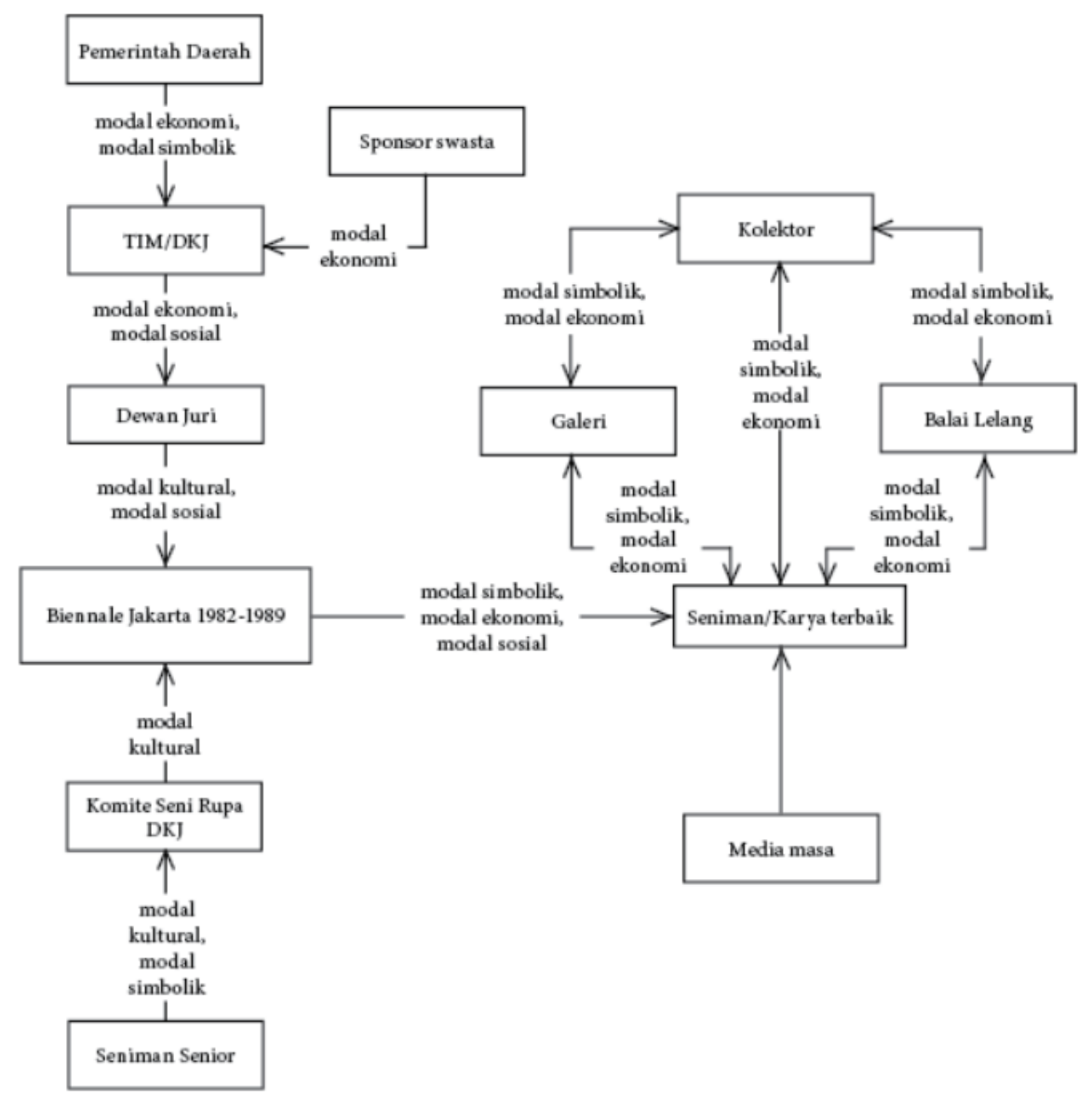

Gambar 2. Struktur relasi antar agen dalam Biennale Jakarta 1982-1989

mengalami kemunduran yang ditandai dengan jumlah pengunjung yang terus berkurang dan acara kebudayaan yang kurang greget.

Sebagaimana kondisi yang disebutkan di atas, menjadi latar dari Biennale Jakarta 1982 hingga 1989. Dengan mekanisme yang diperbarui, Biennale Jakarta hanya menampilkan karya-karya dan seniman yang sudah senior, dengan batasan usia di atas 36 tahun dan secara konsisten berkarya. Pada tahapan ini, DKJ menempatkan diri sebagai agen yang sangat dominan. Meskipun pada kenyataannya inisiatif pihak swasta melalui pendanaan program-program TIM tidak bisa dipandang sebagai suatu yang netral. Dalam pergeseran corak karya yang hadir dalam Biennale Jakarta, kita bisa melihat selain karya seni yang dekoratif dan abstrak yang populer sejak awal tahun 1970-an, hingga kemunculan karya-karya photorealis dan surealis. Misalnya dari karya-karya Dede Eri Supria dan Ivan Sagita.

Karya-karya realis dan surealis tersebut sedikit banyak bercerita tentang kondisi kehidupan masyarakat Indonesia dan menampakkan metafor-metafor yang lebih kritis dalam memandang penguasa. Hal ini berjalan seiring dengan meningkatnya taraf hidup masyarakat Indonesia, termasuk seniman. Kelas menengah yang kemudian hadir dari stabilitas ekonomi dan peningkatan kesempatan pendidikan serta pergaulan dengan dunia Internasional yang kian terbuka, menciptakan masyarakat yang lebih kritis dalam menuntut hak-hak mereka. Hal ini tampaknya cukup mengkhawatirkan bagi penguasa Orde Baru sehingga, secara umum, opresi yang dilakukan Orde Baru kian melemah menuju tahun-tahun 1990-an.

Peningkatan taraf hidup juga dinikmati oleh para seniman yang kondisinya demikian membaik seiring budaya mengkoleksi yang kian marak baik pihak galeri maupun kolektor. Hal ini menciptakan kelas antar seniman. Pemisahan antara seniman senior dengan seniman lainnya pada Biennale Jakarta juga menguatkan penggambaran kondisi zaman yang demikan. Seniman yang kian melambung pun pada akhirnya memandang Biennale Jakarta sebagai ajang yang kurang gengsinya. Hadiah yang dirasa terlalu kecil, hingga manajemen yang selalu tidak sempurna dalam penyelenggaraannya. Sementara di sisi lain seniman yang kurang beruntung menganggap Biennale Jakarta adalah tempatnya seniman-seniman 'emas'. Segala peristiwa tersebut sedikit banyak memengaruhi DKJ untuk akhirnya menghentikan pemberian penghargaan kepada seniman atau karya terbaik.

Pemberian penghargaan dari DKJ berhenti pada 1990, dan setelah masa tersebut, tidak terdapat suatu lembaga atau institusi yang menyelenggarakan kompetisi dan peng- 
haraan seperti DKJ hingga kemunculan Philip Morris Indonesia Art Award (PMIAA) pada 1994.

\section{ANALISIS DAN INTEPRETASI DATA}

Pemberian penghargaan DKJ mengalami suatu fase perubahan. Perubahan tersebut tidak terlepas dari kondisi sosial yang terjadi di Indonesia dan keberadaan tokoh-tokoh yang mengelola ataupun terlibat di DKJ.

Latar sosial pada saat berlangsungnya PBSLI dan Biennale Jakarta berada pada rentang tahun 1974 hingga 1988. Menurut M.C. Ricklefs, pembabakan Orde terbagi dalam fase pertumbuhan Orde Baru (1965-1975), fase keemasan Orde Baru (1976-1988), dan fase keruntuhan Orde Baru (1989-1998) (Ricklefs, 2003).

Berdasarkan pembabakan tersebut, PBSLI dan Biennale Jakarta masuk dalam fase akhir 'Pertumbuhan Orde Baru' dan masa 'Keemasan Orde Baru (1976-1988)'. Pemberian Penghargaan DKJ berada dalam kondisi perekonomian Orde Baru yang sedang berkembang pesat. Setelah mengalami peningkatan pendapatan negara dari melonjaknya harga minyak, Indonesia memasuki tahun pertama membiayai secara mandiri pengeluaran negara. Pembangunan infrastruktur pun kian pesat dan tersentralisasi di Pulau Jawa, khususnya Jakarta. Untuk lebih jelasnya dalam melihat perubahan pada periode penghargaan oleh DKJ akan ditampilkan momentum yang terkait yang dibagi dalam 3 tahapan:

\section{Masa awal pemberian penghargaan oleh DKJ (1974- 1980)}

Protes terhadap keputusan dewan juri yang dikenal kemudian dengan 'Peristiwa Desember Hitam' kemudian memicu Gerakan Seni Rupa Baru pada 1975. Dalam konteks pemberian penghargaan oleh DKJ, golongan pemrotes melihat sikap DKJ yang tidak mengapresiasi keberagaman yang ada dalam seni lukis Indonesia. Pihak DKJ hanya memberikan penghargaan kepada pelukis senior yang menampilkan karya yang 'aman'. Sikap yang diperlihatkan oleh DKJ ini menjadi sangat beralasan ketika dikaitkan dengan karakter pemerintahan Orde Baru yang germar intervensi dan otoritarian. Orde Baru dikenal dengan pemerintahan komando yang mengalami paranoia terhadap kemunculan kembali ideologi-ideologi yang merongrong negara. Jim Supangkat dalam wawancara menyebutkan bahwa pameran PBSLI 1974 merupakan ajang pembuktian pelukis-pelukis Jogja pada masa itu tidak berpaham kiri. Dewan juri yang berasal dari lingkungan ASRI cenderung memilih karya-karya yang non-realisme sosial.

Sikap DKJ yang tidak kompromis terhadap protes-protes ini secara konsisten terlihat dalam rangkaian ajang pemberian penghargaan pada tahun-tahun berikutnya. Dalam pada itu, sebenarnya DKJ juga tidak berkenan bila pemerintah banyak mengintervensi program-program kebu- dayaan TIM, sehingga DKJ cenderung membuka diri terhadap investasi asing untuk akhirnya mengimbangi hak-hak penyandang dana. Hal tersebut bukan suatu perkara yang mudah.

Dalam soal pemberian penghargaan terhadap seniman terbaik respon yang muncul cenderung beragam, namun media massa cenderung lebih banyak menonjolkan kekurangan-kekurangan yang ada pada PBSLI. Seperti yang dituliskan dalam beberapa judul artikel berikut:

1. 'Seniman Harus Punya Sikap dan Hati Nurani Kerakyatan’ Harian Kompas, Selasa 21 Desember 1982.

2. 'Kembalikan Seni Lukis pada Rakyat' Harian Merdeka, Kamis 29 Januari 1981.

3. 'Pelukis Indonesia yang Masih di Menara Gading' Harian Merdeka, Rabu 14 Januari 1981.

4. 'Bukan Modernisasi Melainkan Erorikanisasi' Sinar Harapan, Sabtu 17 Januari 1981.

5. 'Seni Rupa Mencari Perspektif' Berita Buana, Selasa 20 Januari 1981.

6. 'Seni Rupa Indonesia Seni Yang Kesepian’ Minggu Merdeka, Minggu 25 Januari 1981.

Perubahan nama dan mekanisme seleksi ajang pemberian penghargaan DKJ, PBSLI menjadi Biennale Jakarta (1982-1987)

Dengan melakukan perubahan nama menjadi Biennale Jakarta, DKJ ingin menyejajarkan dengan acara serupa di kota-kota besar dunia. Untuk itu mekanisme pemilihan seniman pun diperketat. Hanya seniman senior yang memenuhi syarat saja yang berhak masuk dalam Biennale.

Melalui mekanisme baru tersebut DKJ menampilkan karya dari seniman-seniman yang memang sudah 'mapan'. Dalam tahap ini, terjadi kesenjangan antara seniman yang terpilih dengan yang tidak. Terciptanya kelas antarseniman ini menimbulkan kecurigaan bahwa seniman Indonesia yang terpilih hanya melayani selera elit. DKJ tidak lagi berperan sebagai wadah dari perkembangan seniman Indonesia dan hanya menerima seniman yang sudah jadi. Tulisan kritik pada media masa memperlihatkan kecenderungan hadirnya seniman elit yang muncul dari perubahan mekanisme yang diterapkan oleh DKJ. Hal ini disampaikan oleh Sudarmaji dalam koran Sinar Harapan yang terbit pada 10 Januari 1981. Selain itu, kehadiran pemilik modal yang kian dekat dengan seniman diwakili oleh pertumbuhan ruang pameran, galeri, dan kolektor. Opini semacam itu hadir dalam beberapa media massa. Sementara fakta yang ada, DKJ pun tetap memfasilitasi segala pameran yang masuk melalui proposal kepada mereka. Dalam hal ini, pemberian penghargaan demikian membedakan antara sebuah pameran biasa dengan pameran dengan pemilihan karya terbaik.

Hasrat menyelenggarakan Biennale Jakarta mendapatkan banyak kritikan, pasalnya kepanitian yang dibentuk DKJ hanya terdiri dari sedikit orang, sehingga kerap kali 
dibandingkan dengan Biennale luar negeri yang secara serius melibatkan banyak pengamat dan ahli seni. Namun, bagi DKJ, hal tersebut perlu untuk diselenggarakan dalam rangka mendorong iklim berkarya yang lebih baik. Biennale Jakarta tercatat berlangsung 4 kali, yaitu pada tahun 1982, 1984, 1987, dan 1989.

Hanya pada Biennale Jakarta 1982 yang tidak menyelenggarakan penjurian, sementara Biennale selanjutnya kembali melakukan penjurian dan seniman terbaik mendapatkan ganjaran hadiah. Namun pemilihan karya terbaik yang dilakukan di DKJ pada periode ini sudah berkurang gengsinya. Dengan terlibatnya tokoh-tokoh penting dan pengusaha dalam medan seni rupa Indonesia saat itu memunculkan pilihan untuk berprofesi sebagai seniman, yanpa perlu bergantung pada DKJ. Dapat dilihat pada 1983 berdiri Galeri Mondecor dan pada tahun 1984 berdiri Galeri Edwin yang aktif memilih seniman untuk berpameran di galerinya. Apresiasi dan promosi seniman sudah terbagi antara DKJ dengan ruang-ruang galeri swasta.

\section{Masa akhir pemberian penghargaan oleh DKJ (1989)}

Biennale Jakarta diselenggarakan trakhir kali pada 1989 dengan mekanisme penjurian dan pemberian penghargaan. Selanjutnya DKJ lebih mengedepankan peran kurator dalam proses penyeleksian karya dan seniman yang terlibat.

Pada Biennale Jakarta 1989 ini merupakan titik puncak dari kesulitan anggaran pengelolaan. Biennal ini dituliskan dalam beberapa media massa merupakan Biennale yang digarap secepat mungkin. Pasalnya dana baru tersedia antara satu hingga dua bulan menuju penyelenggaraan, dan itupun berasal dari kemurahan hati Setiawan Djodi yang menjadi sponsor tunggal. Sejak tahun-tahun sebelumnya, penghargaan dari DKJ dirasa menurun gengsinya. Hal ini tidak terlepas dari kemunculan galeri-galeri baik yang komersial maupun non-komersial yang menjadi jalan lain atau jalan alternatif bagi seniman-seniman Indonesia. Selain itu, bila melihat kebijakan Orde Baru dalam mendirikan belasan lembaga kebudayaan daerah dalam program Taman Budaya menciptakan alternatif untuk tidak hanya menyasar Jakarta sebagai tempat berkesenian.

Berdasarkan data di atas, pengaruh dari kondisi sosial politik, dalam hal ini Orde Baru, menjadi salah satu faktor penentu sikap dewan juri dalam mengambil keputusan. Dengan mempertimbangkan preferensi yang dianggap aman oleh Orde Baru kala itu, TIM pada periode 1974-1980 masih berada dalam koridor Orde Baru. Seiring melemahnya pengaruh Orde Baru dan menguatnya peran kelas menengah, TIM membuka diri kepada investor, yang sedikit banyak menjadi suatu yang dipertimbangkan oleh pengurus dalam menampilkan ragam kebudayaan dan tema di TIM. Dengan menerima sumber pendanaan dari pemerintah daerah dan investor, TIM berada di dua 'selera' yang berbeda, selera Orde Baru dan selera kelas menengah yang muncul dan semakin menuntut hak dan kebebasannya.

\section{SIMPULAN}

Berdasarkan pemaparan di atas, perubahan yang terjadi dalam PBSLI dan Biennale Jakarta memperllihatkan pengaruh dari latar sosial tempat berlangsungnya penghargaan tersebut. Begitupun dengan respon publik terhadap hasil dari pemberian penghargaan tersebut. Kesesuaian antara karya yang dimenangkan dengan semangat zamannya seringkali menjadi persoalan yang menyudutkan dewan juri. Dalam hal ini, dewan juri kerap dikaitkan dengan kepentingan tertentu. Adakalanya dewan juri dikaitkan dengan kepentingan sosial politk dan ideologi tertentu, seperti pada masa awal pemberian penghargaan PBSLI pada 1974 hingga 1980. Dewan juri cenderung pro pemerintah dengan mereduksi karya-karya yang bermuatan kritis untuk masuk dalam PBSLI. Sementara pada periode selanjutnya yaitu 1982 hingga 1989 Biennale Jakarta, dewan juri cenderung dituduh sebagai agen dari pengusaha. Hanya memilih seniman yang sudah jadi, siap untuk dikoleksi, dan tidak memihak pada rakyat.

Namun, dewan juri dalam hal ini tidak menjadi satu-satunya faktor penentu selera dalam medan seni rupa. Faktor lain yang bisa menjadi penentu antara lain, pola hidup masyarakat, ketersediaan dana dan waktu luang, koneksi, dan opini yang dibangun melalui media massa. Pada periode PBSLI 1974 hingga Biennale 1989, infrastruktur seni rupa Indonesia masih belum terbangun dengan baik (Pada masa tersebut, baru saja galeri-galeri swasta bermunculan), sehingga keberadaan DKJ dengan jajaran dewan yang terdiri dari budayawan dan seniman senior menjadi sumber wacana dan menjadi perhatian utama, terutama pada periode sebelum 1980-an. Sementara pada periode setelahnya, kemunculan galeri dan kolektor yang memiliki pandangan tersendiri terhadap seni tidak lagi menjadikan DKJ sebagai pedoman dalam mengapresiasi seni lukis Indonesia.

\section{DAFTAR RUJUKAN}

Bourdieu, P. (1984). Distinction A Social Critique of the Judgement of Taste. United States of America: President and Fellows of Harvard College and Routledge and Kegan Paul Ltd.

Dewan Kesenian Jakarta. (1993). Seni Rupa Era '80 Pengantar untuk Bienniale Seni Rupa Jakarta IX, 1993. In D. K. Jakarta, Biennale Seni Rupa Jakarta IX (p. 20). Jakarta: Dewan Kesenian Jakarta.

Iwan Saidi, A., \& Siregar, A. (2016, Mei 1). Dimensi Ruang dalam Karya Rupa (Studi Interdisiplin Terhadap Seni Instalasi Oksigen Jawa Karya Hanafi). Mudra, 31(2), pp. 234-248.

Jones, T. (2015). Kebudayaan dan Kekuasaan di Indonesia. Jakarta: Yayasan Pustaka Obor Indonesia; KITLV-Jakarta. 
Kusumastuti, Y. (2006). Market Forces: A Case Study of Contemporary Art Practice in Indonesia. Semarang: Charles Darwin University.

Pusat Kesenian Jakarta Taman Ismail Marzuki, Yayasan Kesenian Jakarta. (2008). Dua puluh lima tahun TIM. Jakarta: Yayasan Kesenian Jakarta.

Ricklefs, M. (2003). Sejarah Indonesia Modern 12002004. Jakarta: Serambi Ilmu Semesta.

Zainuddin, I. B. (1966). Latar Belakang, Sedjarah Pembinaan dan Perkembangan Seni Lukis Indonesia Modern 1935-1950. Bandung: Departemen Perentjanaan dan Seni Rupa Institut Teknologi Bandung.

Zurmailis. (2018). Strategi Dewan Kesenian Jakarta dalam Mencapai dan Mempertahankan Posisi di Arena Kebudayaan. Yogyakarta: Universitas Gadjah Mada. 